\title{
Marine spatial planning as a tool for promoting sustainable economic development including tourism and recreation in a coastal area: an example from Pärnu Bay, NE Baltic Sea
}

\author{
G. Martin ${ }^{1}$, J. Kotta ${ }^{1}$, R. Aps ${ }^{1}$, M. Kopti ${ }^{1}$, K. Martin ${ }^{2}$, \\ L. Remmelgas ${ }^{2} \&$ M. Kuris ${ }^{2}$ \\ ${ }^{1}$ Estonian Marine Institute, University of Tartu, Estonia \\ ${ }^{2}$ Baltic Environmental Forum, Estonia
}

\begin{abstract}
The Baltic Sea is a dynamic economic region where the competition between various uses of the sea (e.g. recreation and tourism, shipping, fishing, wind farms, extraction of mineral resources) is constantly increasing due to the limited marine area. In addition, the sensitive ecosystem of the Baltic Sea and the potential strong impact of climate changes call for an approach that would also ensure the sustainable development of the coastal marine areas in the future. The main objective of spatial planning of marine areas is to balance various interests. Well-advised spatial planning of marine areas enables to create useful synergies in addition to avoiding conflicts and thereby serve as basis for sustainable development of marine areas by taking into account the characteristics of single marine areas or sub-areas. Marine spatial planning is a practical way to make the use of marine areas more rational, to balance the conflict between social, economic activities and the protection of the ecosystem of the sea and to put social and economic objectives into practice in an open and planned manner. An important result of maritime planning is avoidance/minimisation of conflicts between the activities carried out and planned at sea as well as conflicts between the use of the sea and nature. In the current study, we demonstrate how maritime spatial planning enables to balance interests of different economic sectors together with nature conservation in a limited coastal area with high recreational potential in the NE Baltic Sea. Tools and methods developed within the pilot project in the Pärnu Bay area give a good basis for wider implementation of
\end{abstract}


MSP in the Baltic Sea area and provide a good example of possibilities of sustainable development of main economic sectors balanced with environmental issues in the coastal areas.

Keywords: Marine Spatial Planning, sustainable coastal development.

\section{Introduction}

Intensification of human economic activity in marine areas create potential for conflicts and misuse of limited natural resources. These conflicts escalate especially in the coastal areas where in addition to the economic and nature conservation issues also recreational and aesthetic values of the environment start to play important role. Marine Spatial Planning is a relatively new tool starting to be implemented in many European countries to organise and ensure proper management of marine and coastal resources. There is a lack of good examples of implementation of this approach in the Baltic Sea area and therefore recent series of pilot studies were initiated in the Baltic Sea for developing and testing methodology in different ecological and economic environments. The Pärnu Bay pilot area handled in the current paper is located in the northern part of the Gulf of Riga and encompasses Pärnu Bay and the estuary thereof in the Gulf of Riga, NE Baltic Sea; the land boundary of the area extends from the Matsi Recreation Area in Varbla Rural Municipality to the Latvian border at Ikla. The area is administratively situated in Pärnu County, Varbla, Tõstamaa, Audru, Tahkuranna, Häädemeeste and Kihnu Rural Municipalities and in Pärnu City. The surface of the pilot area is $1990 \mathrm{~km}^{2}$; all influenced by a complex of diverse human use and varied environmental conditions.

The objective of MSP is to determine the general principles for use of the planning area in cooperation with interest groups, having regard to the existing and possible future usage of sea and coast, environmental conditions and requirements of nature conservation. Another objective of the current pilot project was to experimentally implement MSP methodology in the Pärnu Bay pilot area, to find out difficulties, possible gaps in information and methodology and contribute to development of MSP methodology for Estonia.

The necessity of preparing the Pärnu Bay plan is caused by the continuously intensifying use of this particular sea area. The intensity of maritime transport is increasing and new activities have been initiated or are being planned (e.g. introducing areas designated for various water sports, construction of offshore wind farms) that are at times in contradiction with other activities or the objectives of environmental protection. Planning is related to the need to minimise the impacts arising from the use of the sea to the marine environment and ensure sustainable development. A plan of the marine area should help make decisions when planning new activities for the respective marine area and grant a certain degree of assurance for the current users of the sea; their activities have been accounted and shall be considered in the future when new activities are initiated. 
The specific objectives of the current project were to:

- ensure protection and preservation of the marine resources of the Pärnu Bay area;

- ensure protection of area of ecological significance;

- promote minimising and resolving conflicts between human activities and protection of the marine environment;

- minimising contradictions between various human activities and propose solutions; and

- $\quad$ preserve/ensure the development of existing activities characteristic for the region (fishing, maritime transport and ports, tourism and "Summer Capital”, marine research).

The current paper is based on the materials developed in the framework of the project BaltSeaPlan [1].

\section{Environmental setting}

\subsection{Sea and coastline}

The area is a typical for the Gulf of Riga with specific environmental conditions. The salinity of seawater is generally lower in the Gulf of Riga than in the open part of the Baltic Sea, while the concentrations of nutrients are significantly higher. This in turn affects several other environmental parameters such as the transparency of water, which is generally substantially lower in the Pärnu Bay region than in other adjacent marine areas. Pärnu Bay is largely affected by freshwater inflow from the Pärnu River. The high amount of freshwater also brings a substantial amount of organic material that in turn affects the optical properties of the seawater of the region. The seabed topography is typical for the northern part of the Gulf of Riga. The project area is characterised by dominance of shallow coastal waters with maximum depths extending down to merely 15 meters. Seabed deposits in the Pärnu Bay and the open part of the Gulf of Riga generally consist of silt and sand, but there are also extensive areas with boulders and pebbles in the northern part of the project area.

\subsection{Other important environmental characteristics}

The Gulf of Riga is subject to relatively large annual water temperature fluctuations. From the end of June to the middle of August the temperature of the surface water generally remains above $18^{\circ} \mathrm{C}$. The Gulf has some ice cover every winter. Ice usually appears to form in shallow bays in the middle of December. In harsh winters this process is brought forward by about a month and in warm winters is postponed by roughly the same amount of time. Pärnu Bay is the first part of the Gulf of Riga to freeze. The pack ice that is piled up on the shore by strong westerly winds has occasionally even threatened the resort buildings on Pärnu beach. The Gulf is completely frozen during roughly $60 \%$ of winters. Estonia's thickest coastal ice $-90 \mathrm{~cm}$, was recorded in the eastern part of the 
Gulf of Riga during the extraordinarily cold winter, 1941/1942. In average winters the ice cover melts by the end of April. In warm winters the whole sea is free of ice by March. In some winters there has been ice in Pärnu Bay for up to 6 months.

The largest fluctuations in sea level along the Estonian coast have also been observed in the Gulf of Riga. Strong and prolonged western winds raise the water level in the east, and easterlies lower it. In October 1967 the water level in Pärnu Bay rose $253 \mathrm{~cm}$ and in January $2005275 \mathrm{~cm}$ above its average level, respectively. These high sea-levels caused extensive flooding in the town. In December 1959 the level dropped to $120 \mathrm{~cm}$ below the average; as a result many shallow bays dried up and the sea receded occasionally hundreds of metres.

\subsection{Valuable environmental areas}

Owing to low salinity and short geological history of the Baltic Sea area the diversity of the marine biota in the study area is low. Freshwater species generally prevail in the biota [2].

\section{Socio-economic setting}

The coastal area is quite densely populated. The mean population density in the municipalities bordering with the project area is 38 inhabitants per $\mathrm{km}^{2}$ (without Pärnu city 8.8 inhabitants per $\mathrm{km}^{2}$ ). The marine area chosen as the pilot area is intensively used. Activities with a long-standing tradition that have already been established are shipping (shipping lanes and Port of Pärnu), fishing (use of various types of fishing gear) and recreation and related activities (intensively used recreation and coastal areas in Pärnu Bay). In addition the extensive wind energy parks are planned for the project area. Nature conservation activities that encompass the majority of the described territory can also be viewed as a separate type of human use.

\subsection{Existing and planned sea use in the Pärnu area}

The existing interests of marine area uses in the Pärnu Bay pilot area may be divided into larger groups: national nature conservation and sustainable use of natural resources (including scientific research and monitoring), nongovernmental environmental organisations, ports, shipping and shipping lanes, sea tourism, fishing, recreation. The activities of the natural and legal persons belonging to the mentioned interest groups are regulated by relevant Acts and legislation established on the basis thereof, of which the most important are the following: the Planning Act, Building Act, Ports Act, Maritime Safety Act, Water Act, Fishing Act, Earth's Crust Act, Exclusive Economic Zone Act, Nature Conservation Act, Environmental Monitoring Act, Environmental Supervision Act, Public Information Act.

The interests are expressed according to the procedure and terms and conditions provided in valid legislation and the right to use the natural resources is realised on the basis of actually receivable permits, licences, etc. 
Currently granting/receiving the right to use the natural resources of the marine area of the Pärnu Bay pilot area often takes place on the basis of several different Acts. For example, upon encumbering the marine area with construction works, the Law of Property Act (everyone may use a public body of water pursuant to the procedure provided by Acts or established on the basis thereof), Planning Act (county plan for public body of water) and Water Act (the Water Act provides public bodies of water owned by the state (including the territorial sea and inland sea); in order to encumber a body of water with construction works, the superficies licence provided in the Water Act shall conform to the requirements of the respective county plan) shall be relied on. The Water Act and related Acts regulate the construction of construction works that are permanently connected to the shore such as wharfs and jetties, installation of navigational marking (permit for special use of water) and underwater cables (permit by the Government of the Republic, permit for special use of water) and construction of construction works that are not permanently connected to the shore, e.g. wind farms (superficies licence by the Government of the Republic, permit for special use of water).

Applying for a right to use the natural resources for a marine area and granting thereof pursuant to the cases, procedure and terms and conditions provided in the relevant Acts generally eliminates the possibility of a conflict of interests between valid permits and licences. In the event that such a conflict arises for any reason, a mechanism exists to resolve the legal conflict. When characterising the existing situation, it may be said that, based on the valid legislation and the issued permits and licences (with different periods of validity), the marine area of the Pärnu Bay pilot area is already "planned", i.e. divided between the current users in both spatial and time aspects. Further planning/re-planning of the marine area of the Pärnu Bay pilot area is therefore subject to proposals for creating new rights by restricting or amending the existing rights.

The situation can be illustrated by the creation of a new interest group - wind farm developer - on the basis of legislation that determines the procedure and terms and conditions for such creation. Planning a wind farm on the basis of the Fishing Act and the Fishing Rules on a marine area in the Pärnu Bay pilot area prescribed for fishing may serve as an example. In the course of disclosure (Public Information Act) accompanying the marine area plan of the wind farm and the later environmental impact assessment of the plan, the interested parties can reach a solution that satisfies both parties. Upon reaching a compromise (between the wind farm developer and representatives of the fishing industry in this case), further planning of the marine area or amending the existing plan would mean complete or partial limitation of the fishing right in the marine area to be allocated for the wind farm along with making the respective amendments in the Fishing Act and/or the Fishing Rules.

The legally ensured and currently planned human uses of the Pärnu Bay pilot area are indicated in Figure 1. 


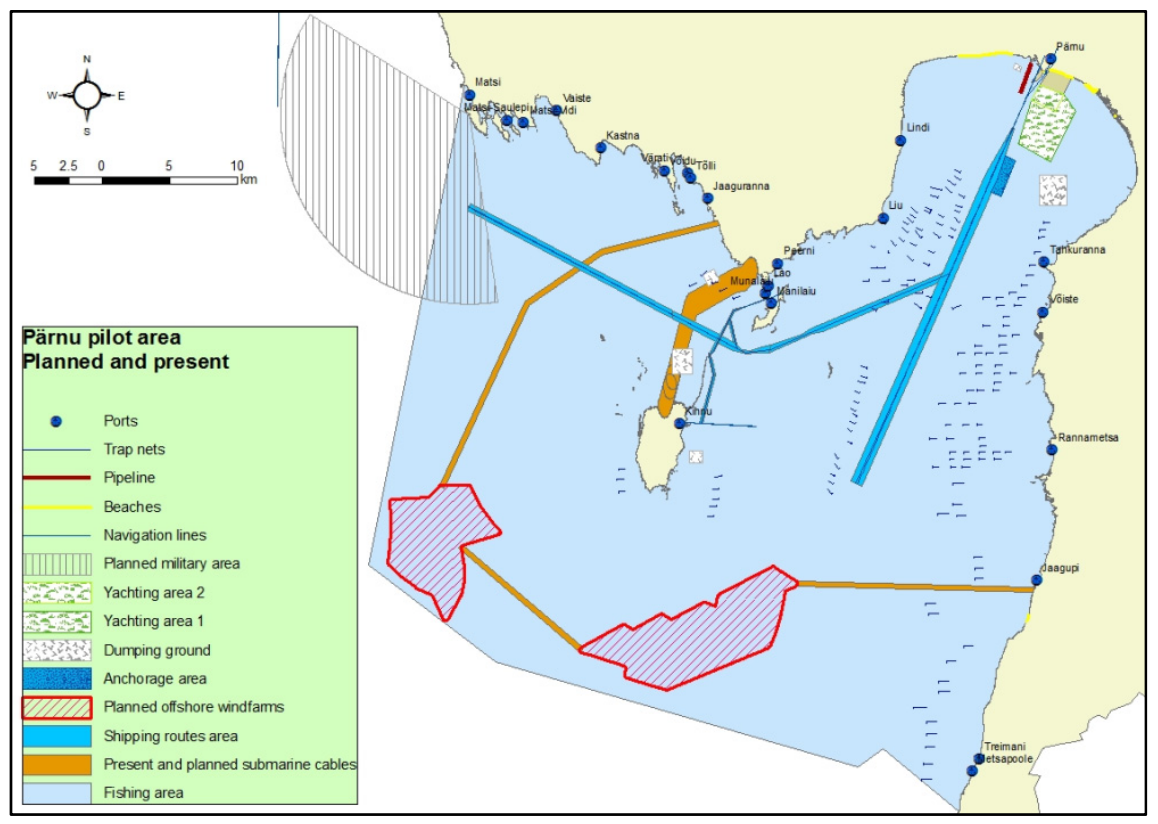

Figure 1: $\quad$ Planned and present human uses of the Pärnu planning area.

\subsection{Tourism and recreation in the Pärnu area}

\subsubsection{Situation and main issues}

Tourism is set to be one of the most important economic sectors for the region promoted by exceptional environmental setting. The length of the coastline of Pärnu County is $242 \mathrm{~km}$, the coastal waters are shallow and among the warmest in Estonia, thus creating favourable conditions for the development of the tourism and recreation industry. Pärnu is annually visited by approximately 500,000 people of whom a third are Estonians and two-thirds are foreigners. The Pärnu County "Sun Circles" that divide the county into four serve as basis for tourism routes: the blue sea region, the land by the sea, the green riverland and the ancient woodland. There were approximately 200 hotels and restaurants in the county in 2009 with $75 \%$ of them in the Pärnu urban area. The proportion of companies with activities directly meant for vacationers is about five per cent in the county. Most of the establishments providing accommodation are located in the territories of local governments that are well known as summer resorts, i.e. in Pärnu and in Audru, Tõstamaa, Häädemeeste, Tori and Tahkuranna Rural Municipalities. Many of the holiday villages and camps are located in coastal regions and mostly active during the peak season, i.e. summer.

The tourism sector is characterised by heavy seasonality. $46 \%$ of the visitors visited the region in the three summer months in 2009 (including $43 \%$ in Pärnu City). As a positive trend, seasonality in general has decreased and the proportion of visitors during summer months only increased again in 2008-2009. 


\subsubsection{Main forcing factors}

The Pärnu County "Sun Circles" that divide the county into four serve as basis for tourism routes: the blue sea region, the land by the sea, the green riverland and the ancient woodland. The location of Pärnu by the sea and the international highway connection of the Via Baltica create good preconditions for movement of vacationers and tourists for moving by sea or vehicle.

\subsubsection{Adopted vision and monitored trends}

According to the Pärnu County Development Strategy 2030+, the following is mentioned as important issues in terms of development of tourism and recreation:

1. activity of the local population as the largest contributors to regional tourism products in shaping the recreation and tourism cluster;

2. modernisation of the infrastructure that supports the current recreation and tourism;

3. creation of an integral development conception of recreation and tourism for the county and directing the activities to more specific target groups and markets;

4. county-wide development of recreation and tourism products; and

5. better usage of the location of the county between two focal points (Tallinn and Riga) and creation of stronger business and marketing relationships with these centres.

\section{Conflict analysis of existing and planned sea uses in the Pärnu area}

\subsection{General overview}

For the described project area in total 12 different uses and 28 combinations of different uses were identified during the stock take process (Figure 2, table 1). In this analysis the area of single use is quite limited and is located mostly in the southernmost and easternmost part of the bay (Figure 3). Major part of the area is recorded as double use - mostly it is combination of fishing and nature protection or fishing and wind farms. In the latter case there is obvious conflict of uses and in case of realisation of the wind farm project the conflict is solved in favour of wind farm developers. In the northern part of the Pärnu Bay the combinations of different sea uses include beach bathing areas, sailing areas, dumping areas and fishing areas. In most cases the other uses are geographically separated creating the conflict only with fishing. Ship routes heading towards Pärnu harbour create zones with multiple uses but in this case there is no conflict between them.

Possible conflicts between sea uses can occur in the area between Kihnu Island and mainland. Here the maximum number of multiple sea uses is recorded (5 uses) from which potentially conflicting are dumping, nature protection and fishing. In this case the conflict should be solved with regulatory mechanisms restricting the activities temporally. 


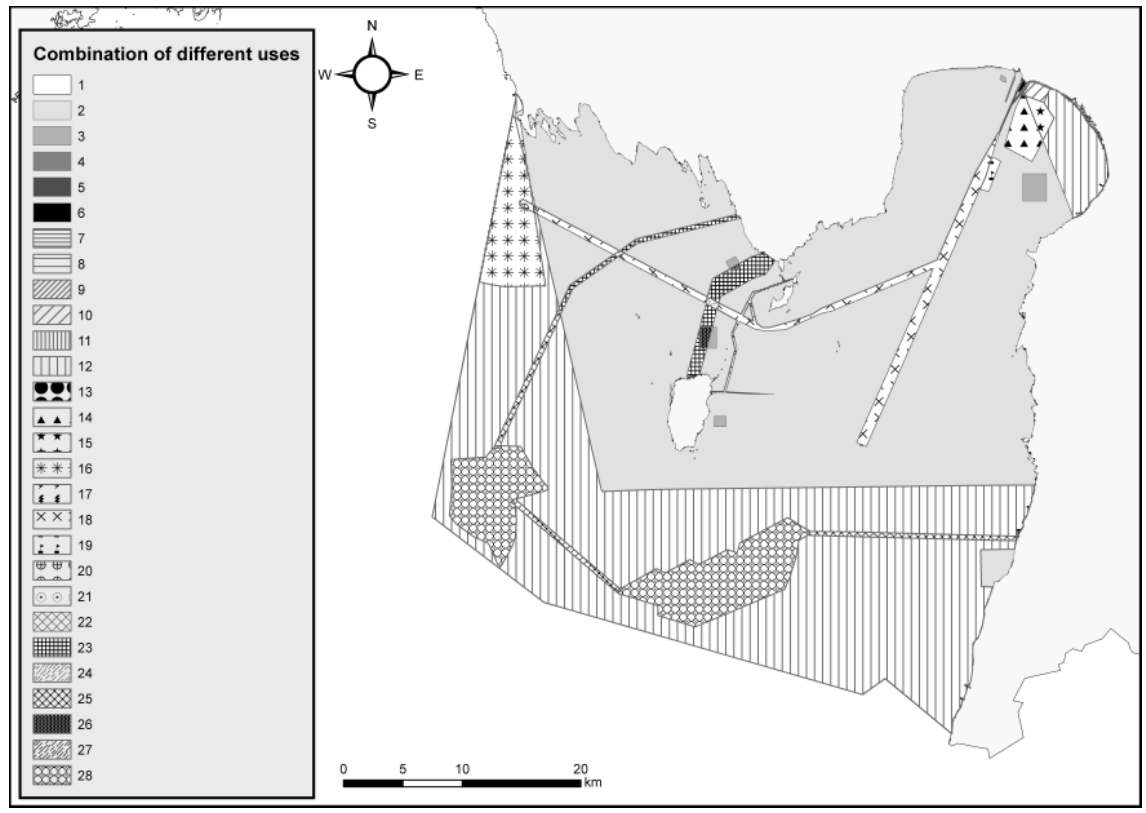

Figure 2: $\quad$ Combinations of different sea uses in Pärnu pilot MSP area (for explanation of coding see Table 1).

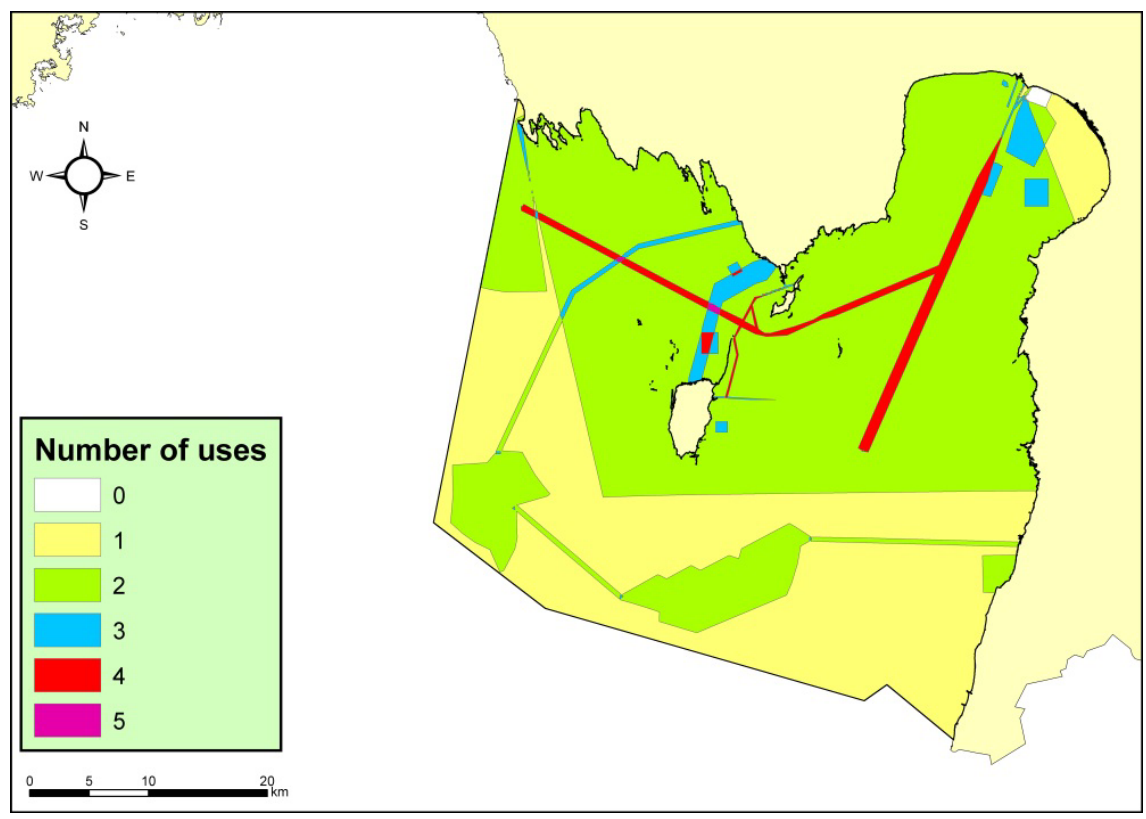

Figure 3: Spatial distribution of different sea uses in the Pärnu pilot MSP area. 
Table 1: Coding of different sea use combinations in the Pärnu planning area.

\begin{tabular}{|c|c|c|c|c|c|c|c|c|c|c|c|c|}
\hline ப் & 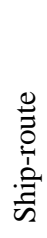 & 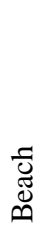 & $\begin{array}{l}\stackrel{\Xi}{\Xi} \\
\stackrel{\Xi}{\Xi}\end{array}$ & 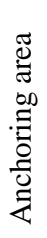 & $\frac{\mathscr{E}}{\mathscr{U}}$ & 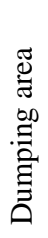 & 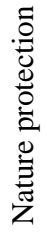 & 吕 & 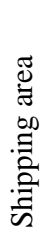 & 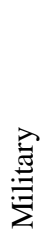 & 怘 & 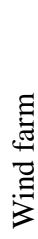 \\
\hline 1 & & & & & & & & & & & & \\
\hline 2 & & & & & & & & & & & & \\
\hline 3 & & & & & & & & & & & & \\
\hline 4 & & & & & & & & & & & & \\
\hline 5 & & & & & & & & & & & & \\
\hline 6 & & & & & & & & & & & & \\
\hline 7 & & & & & & & & & & & & \\
\hline 8 & & & & & & & & & & & & \\
\hline 9 & & & & & & & & & & & & \\
\hline 10 & & & & & & & & & & & & \\
\hline 11 & & & & & & & & & & & & \\
\hline 12 & & & & & & & & & & & & \\
\hline 13 & & & & & & & & & & & & \\
\hline 14 & & & & & & & & & & & & \\
\hline 15 & & & & & & & & & & & & \\
\hline 16 & & & & & & & & & & & & \\
\hline 17 & & & & & & & & & & & & \\
\hline 18 & & & & & & & & & & & & \\
\hline 19 & & & & & & & & & & & & \\
\hline 20 & & & & & & & & & & & & \\
\hline 21 & & & & & & & & & & & & \\
\hline 22 & & & & & & & & & & & & \\
\hline 23 & & & & & & & & & & & & \\
\hline 24 & & & & & & & & & & & & \\
\hline 25 & & & & & & & & & & & & \\
\hline 26 & & & & & & & & & & & & \\
\hline 27 & & & & & & & & & & & & \\
\hline 28 & & & & & & & & & & & & \\
\hline
\end{tabular}

\subsection{Main conflicts in the pilot area}

The main existing conflict in the area occurs between fishing and recreation (water sports). This conflict was alleviated (but still not finally solved) by designating special yachting areas where it is prohibited to hinder or compromise the traffic of vehicles used for water sports (that are marked accordingly) in certain periods. Potential conflicts in case of introduction of new activities include conflicts between nature conservation and other sea uses (the planned military training area, wind farms, also increasing recreation/tourism); conflicts between offshore wind farms and other sea uses (fisheries, shipping, 
recreation/tourism); conflicts between the planned military training area and fishing, recreation/tourism.

\subsection{Methods for dealing with the identified conflicts and solutions}

There are obvious conflicts between the need to utilize the marine resources and the need to manage and protect these resources. However, all existing legal human activities in the Pärnu Bay pilot area are regulated by different relevant legal acts in force. In this sense the sea areas concerned are already "planned" which means that sea space is allocated to different kind of sea uses (not to confuse with sea space allocation to different legal entities) according to legal acts in force.

There are many different complex and often overlapping existing human use rights (public access rights, riparian rights, fishing rights, navigation rights, seabed use rights etc.) that are affected by the emerging maritime spatial planning. However, the planning itself needs also to be performed according to the Estonian Planning Act that regulates relations between the state, local governments and other persons in the preparation of plans with aim to ensure conditions which take into account the needs and interests of the widest possible range of members of society for balanced and sustainable spatial development. The strategic environmental assessment resulting from implementation of the planning policy is organised in the cases and pursuant to the procedure provided for in the Estonian Environmental Impact Assessment and Environmental Management System Act (Saunanen and Vaarmari [3]).

All existing human use rights, including the overlapping ones, are allocated and enforced according to the harmonized system of legal acts in force. Therefore, the existing human use activities performed according to issued permits and licenses usually are not in conflict, and if there is any, then there are the legal procedures in force to resolve these conflicts as appropriate.

Introduction of the new kind of human activity (e.g. development of the wind park area) presumes the democratic process of stakeholder participation which takes into account the long-term strategies in and needs for the development of the economic, social, cultural and natural environment.

Method for dealing with the identified conflicts is the consensus building stakeholder meetings as an obligatory element of the maritime planning process. More specifically, the Mutual Learning methodology should be used. Proposed solutions and recommendations are conflict specific.

Based on the analysis of existing sea uses in the pilot area following conclusions and recommendations have been made:

1. The spatial overlapping of the existing fishing and nature protection uses not presumes the conflict by itself. Based on the results of previous scientific studies the fishery is regulated spatially and temporally with the aim to avoid any irreversible impact. If any new scientific facts based concerns would arise then additional fishery restrictions will be introduced and the Fishery Rules will be amended accordingly.

2. The spatial overlapping of fishing area (existing human use) and the wind park area (planned human use) do not necessarily presume the 
arising conflict resolution. If the planning process will lead to decision to give the permit for the wind park development in the Pärnu Bay then at that stage it is not clear whether the spatial restriction of existing fishing rights with or no compensation will be imposed or not. If some kind of spatial restriction will be imposed then the Fishing Rules will be amended accordingly. It is proposed to resolve this potential spatial conflict either technically based on the provisions of existing legislation or in a course of negotiations of parties concerned. Considerable opposition of environmentalists (important bird area) and the tourist industry (visual pollution vs. the clean horizon what the industry sells) is expected. Fishery opposition will arise only in the case of potential and expected spatial restrictions of the fishing rights.

3. The spatial overlapping of the multiple but not exclusive human uses beach bathing areas, sailing areas, shipping routes, dumping areas and fishing areas in the northern part of the Pärnu Bay (all are the existing sea uses) do not necessarily cause the conflict of sea uses. All these sea uses, including shipping, dumping and fishing are regulated and enforced in a way that that they are not causing any irreversible impact according to best knowledge we have. However, the whole complex environmental impact will be reassessed if introduction of some new type of human use will be planned or new scientific facts on the possible irreversible harm will be revealed.

\section{Recommendations and future steps to implement MSP}

According to the Estonian law (Planning Act) MSP is possible but there are still some legal deficits and unclear aspects [4]. Also the human resources and information basis for MSP are weak especially at the municipalities. National maritime policy should facilitate development of maritime spatial planning. The draft National Development Plan "Estonian Maritime Policy" foresees development of an official pilot MSP in 2013 and preparation of MSPs for all counties by 2020. The latter deadline might be too late, considering development in wind energy sector and other plans for use of the Estonian marine area. In the Estonian circumstances the following is important in order to realize the MSP:

- Establishment of proper legal basis for MSP in Estonia (including landsea planning harmonization, hierarchical planning system, zoning principles in MSP);

- Maritime spatial plans should be developed for the whole Estonian marine area. It is recommended to apply similar principles for spatial planning in marine as well as terrestrial areas, considering thereby the differences arising from different character of sea and land.

- It is advisable to take the existing categories of spatial plans as basis also for planning of marine areas. That means that the general principles of MSP should be set in the national spatial plan (in addition to the territorial sea, the directions can be given also for the EEZ in cooperation with other countries). County level spatial plans should be 
elaborated for the whole Estonian marine area and in case of need also general or detailed spatial plans for certain areas.

- MSP documents should be in line with and basis for the permits/licences issued through specific regulations. For example, if the spatial plan foresees sand mining in a certain area then no permits for conflicting uses are given (before the relevant spatial plan must be changed).

- $\quad$ Sea use development should be sustainable and based on eco-system approach. It should follow the goals of the EU Marine Strategy Framework Directive. MSP should be used as an instrument to avoid cumulative effects of the sea use activities on marine biodiversity;

\section{Acknowledgements}

The current study was performed in the framework of project BaltSeaPlan Partfinanced by the EU (European Regional Development Fund) and with contribution from the Estonian target financed theme SF0180013s08.

\section{References}

[1] Martin, G., Aps, R., Kopti, M., Kotta, J., Remmelgas, L., Kuris, M. 2012. Towards a Pilot Maritime Spatial Plan for the Pärnu Bay. BaltSeaPlan report no 13, 53.

[2] Kotta, J., Lauringson, V., Martin, G., Simm, M., Kotta, I., Herkül, K., Ojaveer, H. 2008. Gulf of Riga and Pärnu Bay. Schiewer, U. (Ed.). Ecology of Baltic Coastal waters (217 - 243). Berlin: Springer.

[3] Saunanen, E. and K. Vaarmari. 2010. Maritime spatial planning. Analysis of valid legislation and solutions for amendment thereof. Estonian Environmental Law Centre.

[4] Hendrikson \& Ko, 2010. Methodology of maritime spatial planning. http://www.siseministeerium.ee/public/Merealade_planeerimise_metoodika. pdf. 